\title{
WOMEN DOCUMENTARY
} FILMMAKERS: FRAMING WAR AND 'POST-CONFLICT' ZONES MAŠA HILČIŠIN 
The representation of mass rape, other forms of torture, and forced exile along with psychological and social consequences of war on women and girls reveals essential elements which have to be brought more into the current public discourse. In contemporary documentary cinema, this discourse is built on a major dichotomy: victims/survivors and perpetrators, representation and signified reality, and recollection of subjective impressions and aestheticism over documentary text. Exploring a range of cinematic representations of war and post-conflict ${ }^{1}$ zones raises many issues of universal and basic human concerns. Critical discourse and the complex relationship between the filmmaker and subject embody some of the key ethical challenges in documentary cinema. By raising issues of sexual violence, deprivation, devastation, threats, and death in a representational mode of documentary cinema, ethics concerns and burdens become one of the core issues for documentary filmmakers. In displaying vulnerable subjects and harsh traumas, documentary text constructs vivid reality which shifts from representational to indexical reflection and steers away from imaginary reflection of the constructed world that might exist, but refer to the world that the viewer actually lives in. Filmmakers selected for this paper opted for an approach based on evidence, factual material, and highly resonant emotional responses. This develops strong rhetoric and appeal on conditions addressed in documentary text. Female documentary filmmakers provide mapping of some of the most critical current issues in politics and society and specific access to human stories and interpretations which grew at the intersection of political activism, feminism, and documentary discourse.

Representation of war and the exploration of political conflict over documentary film text are discussed through recent documentary productions of Lisa F. Jackson's The Greatest Silence: Rape in the Congo (2008), Anneta Papathanassiou's Playing with Fire: Women Actors of Afghanistan (2014), and Yasmin Fedda's Queens of Syria (2014). Each of these documentary texts assembles the specific nature of documentary cinema and its anticipation of massive violence against women emanated by the politics of war. All of them received major documentary film awards for outstanding achievement in directing and advocating human rights.

\section{THE CONGO RAPES}

The first extensive interrogation of mass rape committed in the Democratic Republic of the Congo was documented by documentary filmmaker and activist Lisa F. Jackson whose journey was focused on Eastern Congo, its provinces, and villages. Although estimations vary, according to data published by the American Public Health Association, it has been estimated that "more than 400,000 women ages 15 to 49 experienced rape between 2006 and 2007 in the Democratic Republic of Congo. That is equivalent to 1,152 women raped every day, 48 women raped every hour, or four women raped every five minutes" (International Campaign to Stop Rape and Gender Violence in Conflict, 2011).

In participatory mode Jackson has spoken to a number of women who have been repeatedly raped, mutilated, and tortured by soldiers. War in the Congo involved several armies from Rwanda, Zimbabwe, Angola, Namibia, Chad, Libya, and Sudan. According to the estimations published by the organisation 'World Without Genocide', war and bloodshed caused immense human losses, "since 1996, the Democratic Republic of the Congo (DRC; Congo) has been embroiled in violence that has killed as many as 5.4 million people. The conflict has been the world's bloodiest since World War II" (World without Genocide, 2012).

\footnotetext{
1 Term 'post-conflict' was quoted by the author of the text. Although, the term is employed by the UN and adopted by many political theoreticians as 'post-conflict societies' still in many countries and regions affected by the war conflict remains present on a large scale even when war was officially over. Manifestations of those are continuous rape, active armed groups, and the rise of political tensions in the Democratic Republic of the Congo, or fighting between the Taliban and government and killing of civilians in Afghanistan. Similarly, it applies to other countries and regions such as rising nationalism in Bosnia and Herzegovina or the killing of civilians and artillery attacks in Iraq.
} 
Through the specific access to reality and personal stories, the film text becomes an element of signification and re-construction of ideology (ideology as corpus of concepts based on patriarchal codes). What Jackson explores here is the role of the patriarchal domain which provides legacy and uses rape as a sexual weapon of war. Although there are different understandings and notions on how rape is used as a weapon of war and as an extreme act of violence based on gendered power. Academic Kyle Alexandra (2010, p. 17) argues that current definitions of war rape, including those that define rape as a 'weapon of war', or explaining rape based on sociobiological grounds are "insufficient when it comes to exploring ways to prevent war rape". Alexandra (2010, p. 17) elaborates war rape as "a complex dynamic encompassed by layers of meaning which vary between conflicts. Feminist theory points to the gendered social, political, and economic hierarchies that produce misogynistic cultural norms which are exacerbated in the chaos of war." This supplies important elements to public critical discourse on wartime sexual violence. Researchers Maria Eriksson and Maria Stern took a different direction in exploring and defining war rape. Their research book Sexual violence as a weapon of war? was primarily based on the case of the Congo. Eriksson and Stern $(2013$, p. 17) offer a critical reading of 'rape as a weapon of war' which is commonly used with the two explanatory frameworks to work with; they address the "biological urge/Substitution Theory' (the 'Sexed' Story), and then the narrative explaining the interconnections between gender and militarization (the 'Gendered' Story), which is seen to supplant it, and which underwrites the dominant framing of conflict-related sexual violence."

In Jackson's documentary text, war rape is primarily researched how it is instrumentality used to conquer and humiliate. One of the central questions in The Greatest Silence: Rape in the Congo (2008) is what is happening to survivors of rape and how to collect necessary evidence in and outside of documentary text. Their narratives of war are ghastly images bravely rendered through personal experience which Jackson embroiders in film text. Jackson inverts the expository and participatory mode of representation. She exposes material evidence of disturbing archive images stamped by her own narration and active verbal exchange with subjects. Textual meaning shifts towards the subjects presented in the frame and their stories and comments become central to the film text.

Introduced by the documentary film theoretician, Bill Nichols (1991, p. 107), the expository mode of documentary "relies on interviews with witnesses" utilising also the role of narrator, while participatory mode is situated and centered around "the actual encounter of filmmaker and other" (Nichols, 1991, p. 44).

In The Greatest Silence: Rape in the Congo both of those documentary norms are respected as the filmmaker collects major evidence by interviewing survivors of rape on the one side and perpetrators on the other side, adding personal audio portions to the film text. Conversations with women are centered and structured around present circumstance determined by a complex political reality. All of these conversations convey severe narratives of sexual violence experienced during the war, whether we reflect on 34-year-old Marie Jeanne raped in her home by five soldiers while being in the fifth month of her pregnancy or on 18-year-old Immakilee who was fifteen when she was raped and gave birth as a result of rape; or on 42-year-old Marie Jeanne raped by several soldiers after seeing her husband being killed and his whole body cut into three parts, or Safi who was eleven years old when she was raped (The Greatest Silence: Rape in the Congo, 2008).

The submission of questions has primate over the established narrative. Jackson starts most of her interviews with the present condition followed by subtle deeper diving into the lives of the subjects. The film positions the female body as a political text, inscription of war, and signified territory of systematic political abuse. This is the hidden layer, displayed as internal evidence. The first, more explicit and visible layer, is explained by the biological urge. Jackson confronts both of these 'frameworks' giving the primacy to redefining gendered militarisation over the female body. This critical point is recorded in stories and narratives provided by women where rape was used to conquer, humiliate, and torture. 


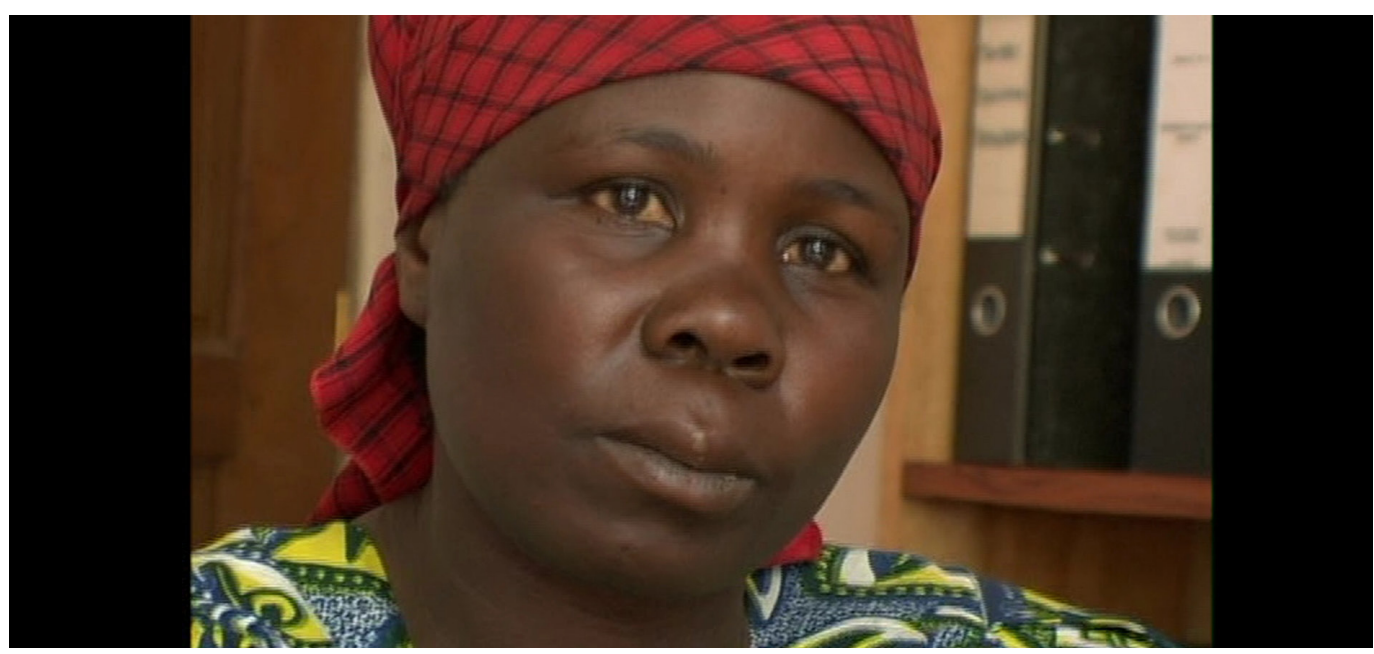

Figure 1: Marie Jeanne. Rape in the Congo (2008)

The structure of the narrative flows from testimonies of survivors done in subtle empirical research which combines conversations, experience, and observations, to random and less structured meetings with perpetrators. "Just ask him to tell me what he did", asks Jackson. "To women?", responds one of the perpetrators. "If she says no I must take her by force. If she is strong, I'll call some friends to help. All this is happening because of the war" (The Greatest Silence: Rape in the Congo, 2008). In the same movie sequence there are about six soldiers, each of them showing with fingers how many women they raped: five, three, seven, ten...

Ethics of representation is experienced here in a continuous effort to collect. Jackson also offers personal space in documentary text by exposing her own experience of gang rape which she survived in 1976 in Washington, D.C. (USA) (The Greatest Silence: Rape in the Congo, 2008). Public space/politics is confronted with private space/female body, which Jackson uses not only to support her own strong argument against ignorance, violation, and moral contradiction, but also as one of the major tools in gaining trust among filmed subjects. Here, the viewer experiences the axiographic physical space as one of the great measures of reality being told (water canals filled with bodies, impoverished areas, modest hospitals and shelter centres, impoverished villages) in documentary film text. Jackson's constant presence in the image (physically in front of the camera, in narration, behind the camera while her voice talking to women could be heard) constitutes an ethics and evidence important for the viewer. Axiographics as a term was introduced by Nichols in order to explore and justify camera gaze and ethical codes identified in documentary mode. Nichols (1991, p. 78) stresses "how the documentary camera gaze takes on distinctive qualities and poses concrete issues of politics, ethics, and ideology in terms of space". In Jackson's documentary narrative, the viewer is directly invited into the film text and challenged by politics of violence. The images that Jackson produces provide valuable evidence on behalf of her argument as well as her own political and human ethics.

Those stories are unforgettable accounts where signified reality becomes a body of images forced by torture/trauma/shame/guilt/abandon. Random (unstructured) conversations with perpetrators are heightened and associated with different elements of realism. This realism supplies different layers of evidence which requires more research and which also reveals devices used in rape, and addresses key geographical areas controlled by armed rebellious groups.

Jackson introduces helpers at later stages of the film (Panzi Hospital in Bukavu), and those subjects built the last, third layer, of the film text. There are not any additional stylistic devices used in the film. Camera narrates subject with the same dynamic as editing. Slower pacing provides specific markers of the socio-historical world imposing the main ethical responsibilities on viewers, the way we relate to those horrifying images, and what we do with them after seeing the film. Hence, Jackson invites us directly to be part of the film as social and political space. 

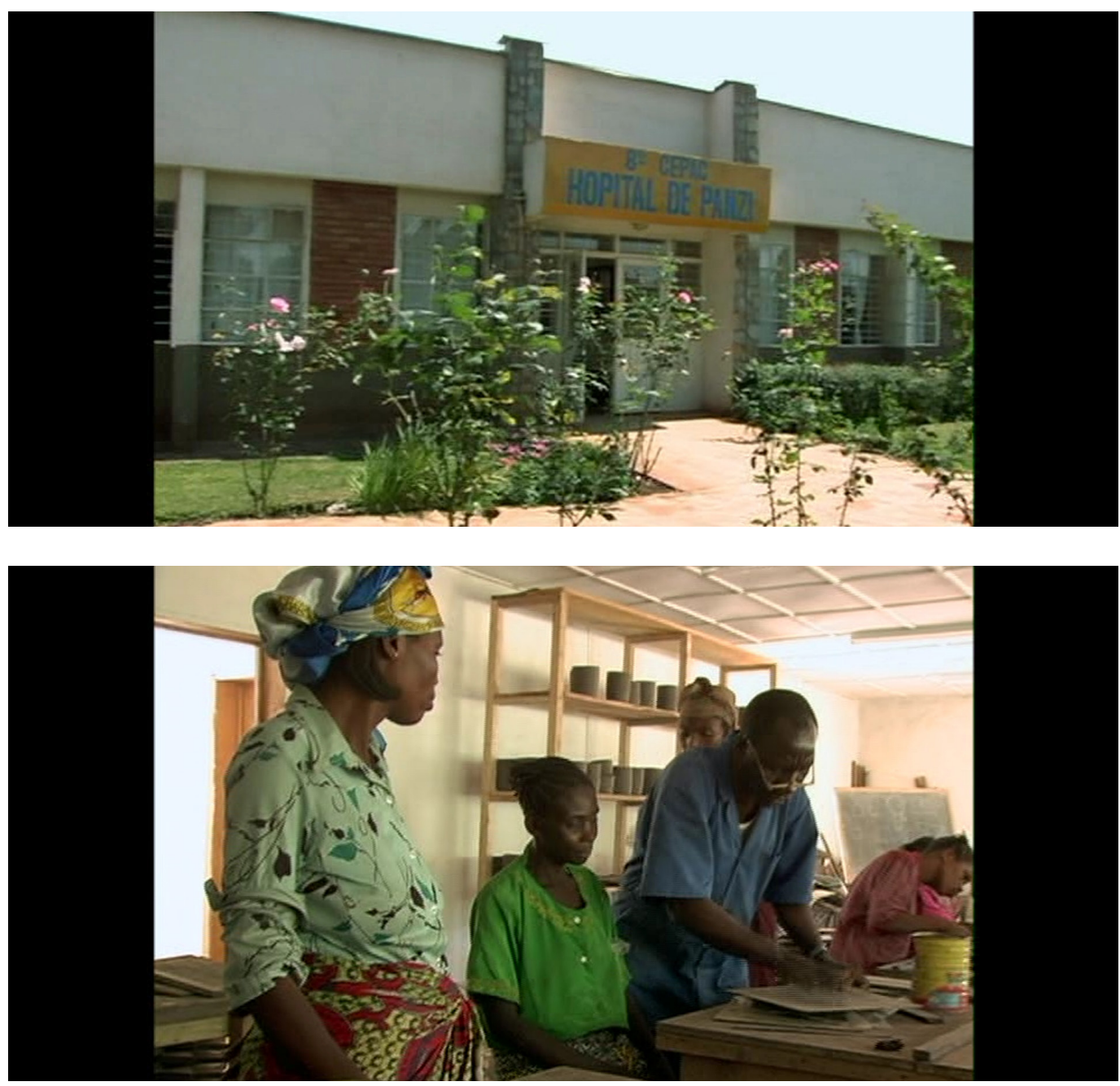

Figure 2 (top): Panzi Hospital. Rape in the Congo (2008)

Figure 3 (bottom): Women for Women International DRCworkshops for women. Rape in the Congo (2008)

\section{PLAYING WITH FIRE}

Playing with Fire: Women Actors of Afghanistan (2014) reminds the viewer that socio-historical context enters documentary text in a distinctive way by providing important sub-text and conceiving discourse which seeds different ethical and political perspectives on the female body, fundamentalism, patriarchal traditions, and repeated violations of women's rights.

Documentary filmmaker Anneta Papathanassiou produces multiple subjects who are layered by the main paradigm of the documentary text. Images and narrative which unfold a continuous presence of the filmmaker within the text (by narration and interviewing as a part of diegetic conversations), and visual representation of spatial/personal/vivid/transformative/ethical/political build together multiple dimensions of the film narrative. Papathanassiou shifts nuances of narrative by exposing vivid spatial representation and placing subjects in different realms.

The dichotomy between public (stage) and personal (home) space breaks linear order of narrative and shifts codifications of different spaces and their significations. In Playing with Fire, the public (stage) becomes self-narrated past, vivid present, sharing the untold while personal (homes) confronts safety, and punishment by family. Echoing the complex political situation, Papathanassiou explores the lives of women actors 
in Afghanistan referring to their voices and her narration in real terms. The UN Women reflected on recent years and the current status on women's rights in Afghanistan. Data exposed shows that violence continues to spread on a large social scale affecting the security, health, and economic status of women, "although considered to be under-reported, over 4,000 cases of violence against women and girls were reported to the Ministry of Women Affairs (MoWA) from 33 provinces of the country in 2010-2012" (UN Women, 2012).

Subjective experience of actresses Breshna Bahar, Roya Heydari, Sajida Nayibee, Leena Alam, humiliated by communities and threatened by fundamentalism and/or by their families, becomes central to the documentary narrative. Real time and subjective time interlace within the thematic plane of the film. Subjectivity transfers here on a different plain as the filmmaker reads the letter sent and signed by the member of the Islamic Taliban Movement (exposed by subject Bahar). Papathanassiou combines expository and participatory modes of representation by bringing together archive images, rhetorical narration, direct addressing, interaction, and empathic identification with the subjects. Logic of the documentary text is built on exchanges between the subjects, interviews, statements, and spatial settings. Axiographics addresses representation of space by shifting towards subjectivity where the representation of politics over the female body becomes central to the film's argument (evidenced by the interview conducted with Enayatullah Baleegh, Professor of the Islamic Law at Kabul University). This constitutes the position of the filmmaker, her presence in the frame, and in the acoustic portions of voice-over narration. The configuration of space stamps the historiographic space of Kabul main Mosque, vivid outdoor markets, theatres, busy Kabul's streets, and Paghman Theatre and Kabul Nendari National Theatre in ruins.

The human gaze constitutes in the film text a way of pointing out the 'signified' and the construction of signifier. The signified is determined by a patriarchal paradigm, acknowledgment of continuous interaction between the filmmaker and subjects, ambivalent personal (home) space, and recollection of memories and experiences. All of them were embodied in vivid staging of Moliere's Georges Dandin, Sophocles' Antigone, and Shakespeare's Romeo and Juliette. Papathanassiou constructs an argument and elaborated reflection by negotiating the distance between her, the subjects, and the viewer's gaze which is justified by the filmmaker's strong response to a socio-historical world and calling for action. She does not develop any specific conventions which relate to expository and/or participatory modes, but renders her own presence in the documentary text as an embodied medium which is actively involved in a contingency of real events. The presentation of the subject could invoke an impression for the viewer that the subject is portrayed as a powerless victim (which is especially arguable during the interview with Breshna Bahar who was attacked by her nephews and ended up in the hospital because of injuries) where the filmmaker remains behind the camera and retains the controlling voice by displaying different questions, but Papathanassiou's subject is not nameless, and her representation provides an important piece of evidence of dreadful pressures and complexities of religious fundamentalism. The film's argument is carefully treated here and it provides close witnessing of the represented reality. The other voice, the voices of perpetrators could be also placed within this framework for evidential support.

Violence and threats as storylines are exposed to fill a narrative function. This is revealed in the thematic plain of the film: the authority of leading local politicians, personal active participation of the filmmaker, and enduring lives of women provide a dramatic device and climax with a powerful conclusion. An ideological approach in constitution of one's own subjectivity is transferred here on a wide social plane. Papathanassiou does not steer away from constitutive subjectivity; instead she offers a platform which explores mythological/historical/tangible evidence/ recollected statements and thoughts/sociohistorical fragmentarity. The ontological claim of a subjective approach refers to the representative strategies used in the film, on the one side. On the other side, the political plane relies on argumentative interrogation of the subjects' lives and their personal rhetoric. Subjects structure an imminent field of norms and values confronting identities of 'fatherland', 'family', and 'otherness'. The evidentiary status of Playing with Fire lies within a larger system of political and subjective dimensions of documentary text. 

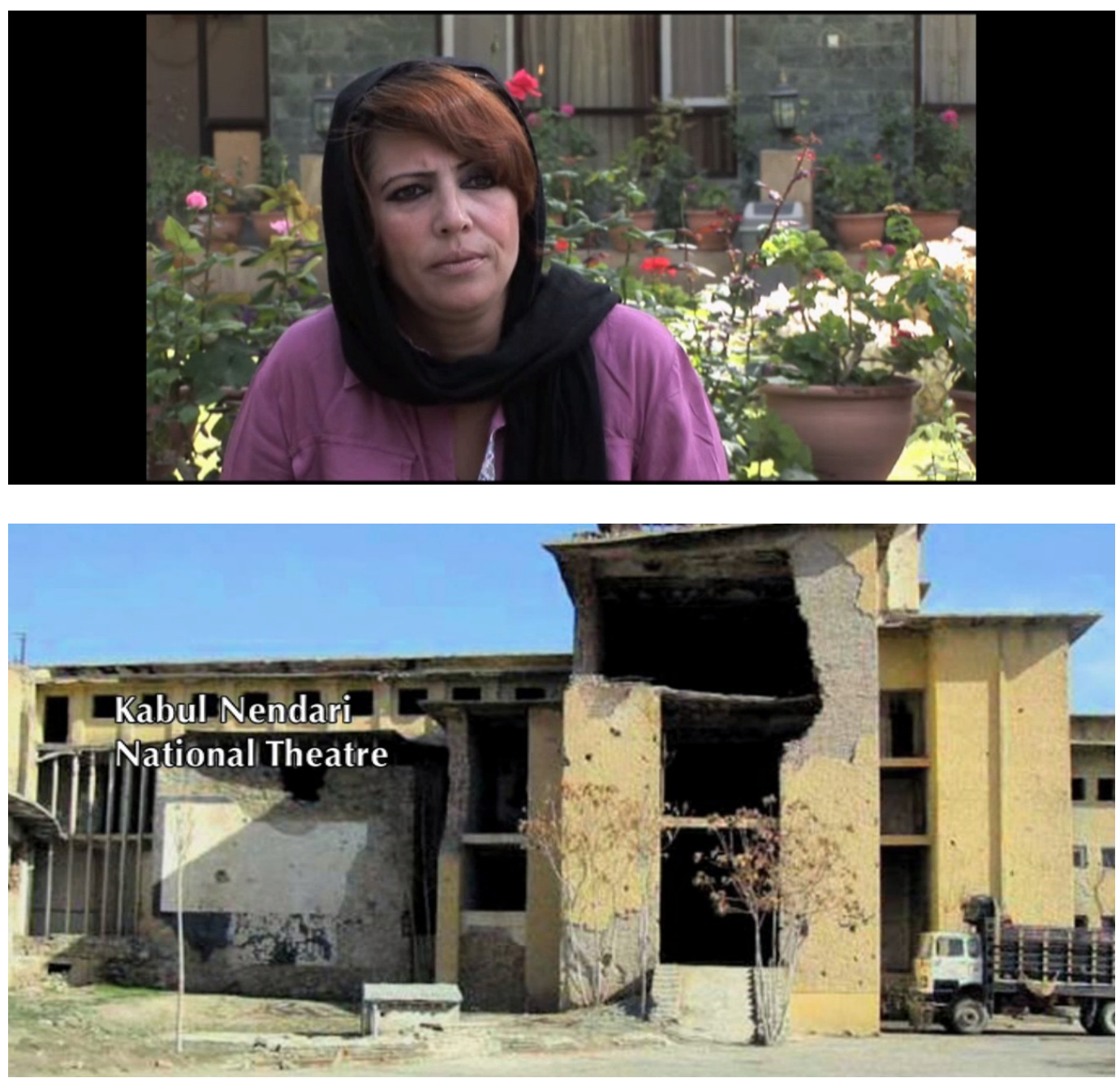

Figure 4 (top): Breshna Bahar. Playing With Fire (2014)

Figure 5 (bottom): Kabul Nendari National Theatre.

Playing With Fire (2014)

\section{QUEENS OF SYRIA}

In framing the devastating war in Syria, director Yasmin Fedda offers a different framework in further exploration of the burning conflict. She places her subjects on the stage to perform their own narrative. The basis for the narrative was used from the mythological ground of "The Trojan Women". Originally written by Greek playwright Euripides, The Trojan Women is ancient testimony with ontological propositions to women's suffering in war. Ontological is found in person-to-history transaction of experience, involving transition of knowledge, socio-historical reality, and personal evidence of trauma as one of the major tools to go through three arcs of mythological tragedy. In Queens of Syria (2014) an apparent subject is exploration of mythological social platform within the intersection of contemporary warfare. But in sharing that narrative together with other women, the filmmaker shows serious attention to causalities of the war in Syria underlying and mirroring catastrophes and horrors from both tragedies.

Fedda's subjects are dozens of Syrian women who were forced to exile, to flee from war and find their base in Amman, Jordan. While staging "The Trojan Women" they share stories of violence, enslavement, and tremendous losses. Fedda operates from the inside, providing a vivid realm of personal narratives. She is not visible in front of the camera, yet her device is in every corner of physical space. The presence of Syrian women serves as an index of their relationship to the filmmaker. A historical world re-created by subjects 
becomes the main scene of the documentary text. The camera's gaze produces here two distinct frames: one is mechanical which allows the viewer to experience the physical realm of rehearsals and plays in the process of creation. Another one is the metaphorical, which transfers and interlaces deep personal connotations formed upon complex social and political circumstances. The Syrian Centre for Policy Research (SCPR) displayed statistics of the death toll and displaced people in the report 'Alienation and Violence: Impact of Syria Crisis Report 2014':

"Over half the population (52.8 per cent) were dislodged as they left their homes looking for safer places to live or better living conditions elsewhere... The appalling loss of life continues to be among the most horrific feature of the armed-conflict, as the death toll increased in the past year to reach 210,000 persons killed. Together with the 840,000 people who were wounded, 6 per cent of the population were killed, maimed or wounded during the conflict" (The Syrian Centre for Policy Research, 2015).

Fedda's ethical response is rooted in empathy and observation of the human experience rather than in intervention while respecting public space and stage space. Both of these spaces confront recurring examples as a constant reminder of reality being told through narrative comprehensions: expressions, recurring lines, movements, and repetitions. Fedda's intervention operates more in the quiet exploration of Fatima's, Suaad's, Maha's, and other stories. This is the intervention of searching for untold stories, hidden 'measurements' of human suffering, corners of refugees homes, souls that yearn for lost homes and a happy past, loss of their relatives, collection of memories, shelling, and funeral rites. This intervention is not actuated by a mechanical or narrative device, but by human need to look for more layers exploring the complexity of the human experience in war. The subjective camera displays personal refugee homes in Amman. "Look at me. You will find a tragedy walking on two legs", says Suaad in Queens of Syria (2014).

The politics of personal space maintains boundaries which Fedda constitutes throughout the whole film. The presentation of subjects on a stage and during rehearsals is revealed in observational mode of representation, placing the subjects in the centre of socio-historical reality. Fedda establishes her own ethical and normative codes, shifting the spatial representation which serves to contextualise public/personal, theatre space/home space, mythological past/harsh present. Long and medium shots renders spatial positioning of refugees' homes and the modest surroundings inhabited by women and their families who managed to escape the war. The invisible filmmaker who observes subjects on the theatre stage and during rehearsals becomes an exhaustive observer and almost becomes like another subject of the film by persistent multiple takes of inside space, providing insights into personal lives and psychological depth of wounds, scars, and exodus. This causes even more need for the viewer to get access to the inside space, outside of the stage.

Fedda applies linear narrative which chronologically employs three arcs of structure. Each arc gradually brings elements of personal women stories to the whole catharsis in performing their own tragedies. Catharsis in Queens of Syria is not the final; it is the stage of around 30 of women who stayed until the end of the production, who renders theatre space, dressed in black, lighted with basic lighting, sitting in the same row and telling their stories. Catharsis here is open, and unfinished as the conflict itself in Syria, and as additional testimony to other stories of women who were systematically neglected and under-told. Representation and documentary text provides here that physical capacity which offers historical construct and women's narrative on war. Spatial representation operates here as a matter of ethics and confronts the viewers with the core issues, conscience, and social responsibility. It implies ontology and importance of historical and contemporary placement of eternal themes and tales of women as symbols of concurred territories, political realms, and literal plane of women's struggle to survive in the aftermath of war. 

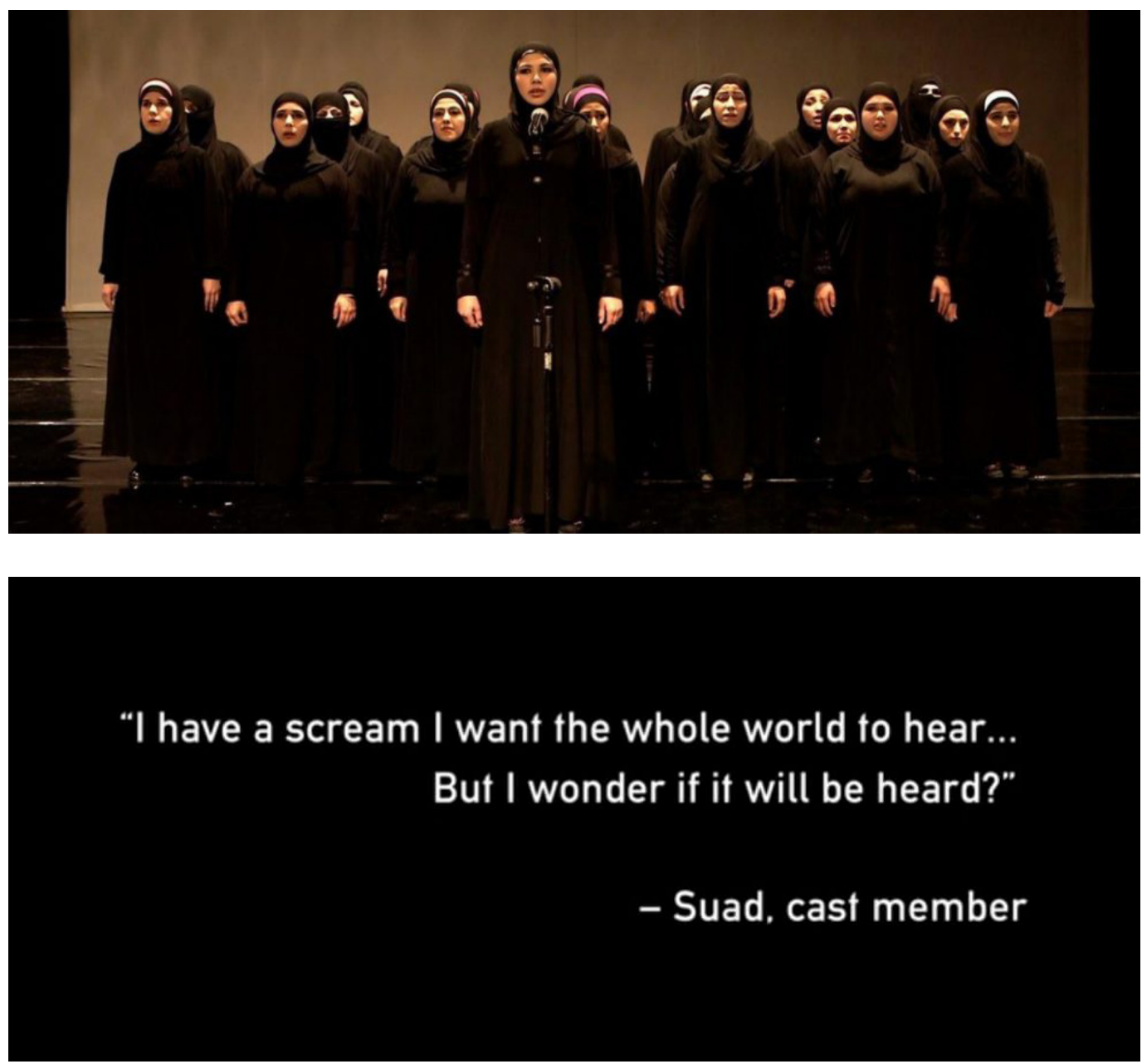

Figure 6 (top) er Figure 7 (bottom): Screenshots from Queens of Syria (2014)

\section{INDEXICAL BIND AND BREAKING THE SILENCE}

Factual materials presented in all three analysed and displayed documentary texts (witnesses, testimonies, and documents) are persuasive strategies applied by filmmakers and subjects of the films in building the solid ground of evidence. Evidence creates an indexical bond between the images presented in the films, their rhetoric, and signified function. In the essay "Mirrors Without Memories", Linda Williams reflects on complexity of the notion of truth in documentary text. She notices how truth in the documentary tradition cannot be purely transparently transmitted and guaranteed concerning representational aspect of documentary mode. However, Williams (1998, p. 386)elaborates that "instead of careening between idealistic faith in documentary truth and cynical recourse to fiction, we do better to define documentary not as an essence of truth but a s a set of strategies designed to choose from among a horizon of relative and contingent truths."

The juxtaposition of compelling images and alarming testimonies attach feelings of responsibility and social conscious in an immense way. Each of these documentary texts demonstrates persuasive cases of damaging and devastating violence happening against women in war and post-conflict zones. Documentary narratives here tend to be structured around factual merits of rape and other forms of physical and psychological violence. Evidence displayed has the ability to convince flows from one image/statement to another in exposing severe problems and violations of human rights. Rhetoric includes argumentative aspects of the documentary film text by facing the 'other side', questioning perpetrators, and confronting leading local politicians. 
Another level of proof is the author's proof which heavily depends on narrative constructions employed over the film text, and quality and accuracy used during the process of representation. A message comes here from the structured interviews, archive resources, and ethical space. Recurring images of rape survivors' testimonies, exile, warfare, beatings, and death threats unfold disturbing representations and indexical connection signs and connections to the real. Although many film theoreticians emphasise the importance of seeing documentary as representational medium and subjective device. In addition to that, film theoretician Stella Bruzzi (2000, p. 4) stresses the role of the representational when negotiating reality between spectatorship and documentary film text, "the spectator is not in need of signposts and inverted commas to understand that a documentary is a negotiation between reality on the one hand and image, interpretation and bias on the other." Those filmmakers provide valuable and important access where documentary film narrative excess realm of representation and becomes dynamic notion of plural conceptions (text, movements, image design, narrative) in order to display how the war and post-conflict world feel like. Such calls make an emotional appeal and social consciousness. The question remains whether those calls will ever fully resonate with the rest of the world.

\section{REFERENCES}

Alexandra, Kyle (2010) 'War, Society, and Sexual Violence: A Feminist Analysis of the Origin and Prevention of War Rape', Hohonu - A Journal of Academic Writing, 8, 17.

Bruzzi, Stella (2000) New Documentary: A Critical Introduction. London: Routledge.

Eriksson, Maria and Stern, Maria (2013) Sexual violence as a weapon of war? Perceptions, prescriptions, problems in the Congo and beyond. London: Zed Books.

International Campaign to Stop Rape and Gender Violence in Conflict (2011) Stop Rape in Democratic Republic of Congo. Available at: http://www.stoprapeinconflict.org/dr_congo (Accessed: 11 July 2016).

Nichols, Bill (1991) Representing Reality. Bloomington: Indiana University Press.

The Syria Trojan Women Project (2016) Queens of Syria UK Theatre Tour. Available at: http://www.syriatrojanwomen.org/ index.html (Accessed: 12 July 2016).

The Syrian Centre for Policy Research (2015) Alienation and Violence: Impact of Syria Crisis Report 2014. Available at: http:// scpr-syria.org/publications/policy-reports/scpr-alienation-and-violence-report-2014-2/ (Accessed: 15 July 2016).

UN Women (2012) Afghanistan. Available at: http://asiapacific.unwomen.org/en/countries/afghanistan (Accessed: 13 July 2016).

Williams, Linda (1998) Mirrors without Memories: Truth, History, and The Thin Blue Line. Edited by Barry Keith Grant and Jeannette Sloiowski. Detroit: Wayne State University Press.

World Without Genocide (2012) Democratic Republic of the Congo. Available at: http:/ /worldwithoutgenocide.org/ genocides-and-conflicts/congo (Accessed: 11 July 2016). 